\title{
KILKA UWAG NA TEMAT ANTYCZNEJ METROLOGII ORAZ CERAMIKI ATTYCKIEJ OKRESU GEOMETRYCZNEGO I ZASAD JEJ DEKORACJI
}

\section{A FEW REMARKS ON ANCIENT METROLOGY AND ON ATTIC GEOMETRIC POTTERY AND ITS DECORATION}

\author{
Ewa Bugaj \\ Instytut Prahistorii, Uniwersytet im. Adama Mickiewicza \\ ul. Umultowska 89D, 61-614 Poznań, Poland \\ ebugaj@amu.edu.pl
}

\begin{abstract}
The article deals with the ancient metrology and a possible recognition of the rules determining ornamentation observed on Attic geometric pottery. While referring to former studies, the author presents ornamentation of Attic geometric pottery, revealing an exceptional standardisation and repetitiveness of elements, as having two developmental tendencies. One concerns horizontal arrangement of decorative motifs, placed in surrounding belts, while the other decoration is put in vertical panels, focusing. These both tendencies in the course of development of Attic geometric period become one harmonised whole. It is also possible to demonstrate on an example of monumental became from Athens (inv. NM 804), that the vessel was exactly twice as tall as the biggest width of its body, as well as that ornaments covering its whole surface have been made according to an accepted module. The author suggests that such a way of thinking and ordering activities should not be interpreted as proving the beginnings of classical mathematical thinking, which is to develop later. However, metrological analyses of ancient artefacts suggests that such objects as Attic geometric pottery may permit recognition of already existing disposition of its creators for visual representations of experienced reality and for attempts made to generalise these experiences.
\end{abstract}

KEY WORDS: ancient metrology and measurement systems, Attic geometric pottery, cognitive archaeology.

W niniejszym artykule chcę zwrócić uwagę na kwestię możliwości rozpoznania zasad rządzących dekoracją na attyckiej ceramice geometrycznej. Następnym celem rozważań będzie namysł nad tym, czy wskazane zasady dekoracji owych naczyń mogą odnosić się do prawdopodobnych, wypracowanych już wówczas sposobów dokonywania pomiarów w oparciu o jakieś umownie przyjęte miary odpowiadające wielkości określonej części naczynia - to jest o moduły. Podniesiona zatem będzie 
kwestia starożytnej metrologii oraz kognitywnego rozwoju człowieka w przeszłości, który można starać się rozpoznać także dzięki badaniom archeologicznym. Przed omówieniem ceramiki attyckiej datowanej na wczesną epokę żelaza chciałabym podzielić się kilkoma refleksjami na temat natury źródeł dotyczących metrologii, a pochodzących ze świata antycznego, i badań nad nimi.

Poszukiwanie powiązań między sztukami plastycznymi, a w szczególności zasadami konstruowania oraz dekorowania dzieł i określonymi zasadami metrologii, które możemy rozpoznać, ma długą tradycję na gruncie badań sztuki greckiej, aczkolwiek problematyka ta nie należy do zagadnień podejmowanych najczęściej. Największym zainteresowaniem wśród badaczy cieszyły się z reguły tematy dotyczące rozpoznania klasycznego kanonu w rzeźbie i w architekturze, gdyż ówcześnie wytwarzanie dzieł zakładało z góry ich formę, która obowiązywała rzemieślnika. Istniejąca dla każdego dzieła forma obowiązująca wykonawcę to kanón, który na gruncie wyrobów plastycznych był odpowiednikiem nazwy nomós w muzyce. I podobnie jak greccy muzycy ustalali lub wypracowywali swój nomós, czyli prawo, tak greccy rzemieślnicy parający się wyrobem dzieł plastycznych oraz konstruowaniem budowli ustalali swój kanón, czyli miarę. Poszukiwali jej, następnie jakąś wybraną stosowali, by po pewnym czasie szukać nowej - to był ciągły proces zmian, poprawiania, doskonalenia. Owe klasyczne prawa i miary dotyczyły głównie proporcji i najczęściej dawały się wyrażać liczbą - były numeryczne. Określały na przykład, ile razy w doskonałej kolumnie trzon powinien być większy od kapitelu, a ile razy w doskonałym posągu tułów większy od głowy (Tatarkiewicz 1988, s. 57). W ten sposób powstawały moduły, czyli umowne jednostki miary odpowiadające wielkości określonego elementu i służące do wyznaczania proporcji oraz wzajemnych zależności wszystkich elementów całości.

$\mathrm{Na}$ gruncie archeologicznej refleksji naukowej dotyczącej starożytnej greckiej wytwórczości wspomniane poszukiwanie powiązań między zasadami konstruowania i dekorowania dzieł a sposobami dokonywania pomiarów (miernictwem) podnoszone bywało głównie w powiązaniu z namysłem nad rozwojem systemu numerycznego w matematyce starożytnej i nad funkcjonalnym zastosowaniem geometrii, jak również $\mathrm{w}$ związku z próbą dotarcia do antycznego pojmowania tego, co jest podzielne i co za takie nie uchodziło (Jones 2000, s. 73; Tobin 1975, s. 307).

Niemniej jednak sama architektura, plastyka i rzemiosło greckie dostarczają wielu przykładów wykorzystania miar, a nawet „zasad matematycznych”, które musiały mieć zastosowanie przy ich wznoszeniu i wytwarzaniu, aczkolwiek można przypuszczać, iż wypracowanie i wdrożenie jakiegoś modułu najczęściej nie wymagało posłużenia się kalkulacją matematyczną, bo matematyka w sensie dociekania naukowego rodzi się dopiero w okresie hellenistycznym (Russo 2005, s. 46). Zapewne wynikało to $\mathrm{z}$ samej praktyki rzemieślniczej i z obserwacji natury, a przede wszystkim z doświadczania wielkości ludzkiego ciała. Można za Anną Pałubicką powiedzieć, iż dominowało myślenie w perspektywie poręczności lub, jak zamien- 
nie je ta badaczka określa, myślenie spontaniczno-praktyczne, aczkolwiek zaczęło ono być przezwyciężane właśnie na terenie świata greckiego wraz z rozwojem filozofii w tym starożytnym środowisku (Pałubicka 2006, s. 45-68).

Liczne wzmianki na temat wykorzystania miar pojawiają się również w starożytnych źródłach pisanych. Dla przykładu można wspomnieć, że świątynie greckie i mające zastosowanie $\mathrm{w}$ ich wznoszeniu proporcje są opisane przez Witruwiusza (Suppes 1991, s. 352-354). Architekt wymienia także idealne proporcje ludzkiego ciała, do których odnoszone są pozostałe miary - a przekaz ów został zilustrowany i rozpowszechniony w nowożytności przez Leonarda da Vinci oraz zachowany w znanej rycinie z końca XV w. po Chr., ukazującej tzw. człowieka witruwiańskiego, znajdującej się obecnie w zbiorach Gallerie dell'Accademia w Wenecji (ryc. 1).

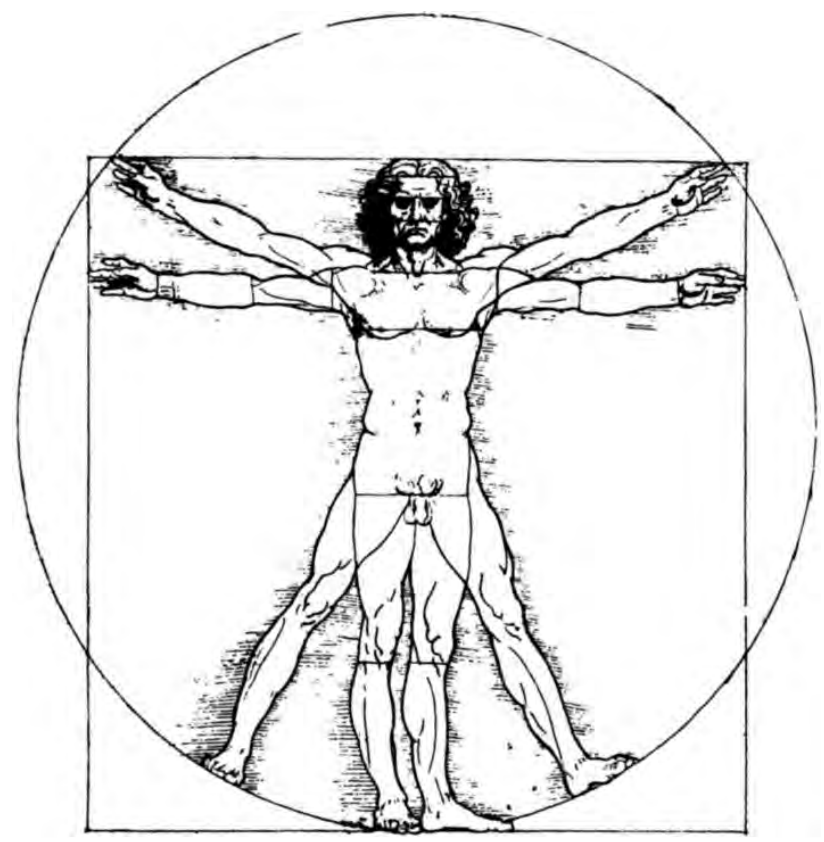

Ryc. 1. Schematyczny rysunek tzw. człowieka witruwiańskiego. Uproszczony szkic na podstawie grafiki Leonarda da Vinci (oprac. E. Bugaj)

Fig. 1. Schematic drawing of so called Vitruvian man. Simplified draft on the basis of the graphics by Leonardo da Vinci (by E. Bugaj)

U Witruwiusza znajdujemy następującą wypowiedź:

Kompozycja świątyni polega na symetrii, której praw architekci ściśle przestrzegać

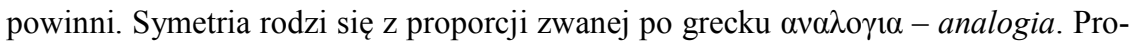
porcją nazywamy zastosowanie ustalonego modułu w każdym dziele zarówno do członów budowli, jak i do jej całości, z czego wynika prawo symetrii. Żadna budow- 
la nie może mieć właściwego układu bez symetrii i doboru proporcji, które powinny być oparte ściśle na proporcjach ciała dobrze zbudowanego człowieka (M. Vitruvius Pollio, De Architectura, 3.1.1) ${ }^{1}$.

Aplikacja proporcji liczbowych do pomników oraz budowli monumentalnych na terenie świata greckiego na większą skalę najprawdopodobniej miała miejsce dopiero ok. połowy VI w. przed Chr., co może m.in. poświadczać materialnie datowany na ten okres, a pochodzący z Paros tzw. kapitel Archilocha z późniejszymi inskrypcjami, dzisiaj znany już tylko z dokumentacji rysunkowej (Campbell 2007, s. 108, ryc. 16). Platon z kolei wypowiada się na temat proporcji matematycznej w Timajosie (31c-32a), wskazując na jej bardzo ciekawą własność. Twierdzi, że jest ona „najpiękniejszym wiązadłem" - i to takim, które tworzy ,jedno, jedyne jestestwo",2 z rzeczami, które łączy (Campbell 2007, s. 109; Heller 2013, s. 26-27).

U Pliniusza Starszego natomiast można znaleźć wzmianki dotyczące kanonu (podkreślenie - E. B.) Polikleta, nazwy odnoszącej się zarówno do teoretycznego traktatu o sztuce rzeźbiarza z Sykionu, jak i posągu, który wykonał. Pliniusz przytacza ponadto na kartach swej Historii Naturalnej wzmianki na temat wielu innych rzeźbiarzy, jak również ogólnie omawia ich prace, w tym mające zastosowanie zasady proporcji. Odnośnie do Polikleta pisze on:

Polyclitus Sicyonius, Hageladae discipulus, diadumenum fecit molliter iuvenem, centum talentis nobilitatum, idem et doryphorum viriliter puerum. fecit et quem canona artifices vocant liniamenta artis ex eo petentes veluti a lege quadam, solusque hominum artem ipsam fecisse artis opere iudicatur ${ }^{3}$ (G. Plinius Secundus, Naturalis Historia, 34.19.55; podkreślenie - E. B.).

Zachowały się dwa małe fragmenty tekstów samego Polikleta, jak również wzmianki u innych autorów - u Filona Mechanikusa z III w. przed Chr., a ponadto u autorów późniejszych - u Plutarcha oraz medyka, Galena (Pollitt 1990, s. 75-79; Stewart 1978, s. 124-127; Campbell 2007, s. 298; Tobin 1975, s. 319-321). Niemniej owe przekazy historyczne są przedmiotem krytycznego namysłu, a odniesienie wymienianych w nich zasad miar i proporcji do zachowanych reliktów materialnych, jak i do możliwej oraz podzielanej wówczas wiedzy matematycznej i geometrycznej, a także do danych dotyczących historycznych miar i wag obowiązujących w konkretnym okresie w poszczególnych regionach świata greckiego, pozostaje przedmiotem studiów szczegółowych, dyskusji i wciąż nowych interpretacji (por. szerzej na ten temat: Jones 2000, 2001).

\footnotetext{
${ }^{1}$ Cytuję za: Witruwiusz, O architekturze ksiag dziesięć (Księga trzecia, I.1), przeł. Kazimierz Kumaniecki, Prószyński i S-ka, Warszawa 1999, s. 71-72.

${ }^{2}$ Cytowane wyimki z: Platon, Timajos, przeł. Paweł Siwek, PWN, Warszawa 1986, s. 38-39.

${ }^{3}$ Cytuję za: http://penelope.uchicago.edu/Thayer/L/Roman/Texts/Pliny_the_Elder/34*.html.
} 


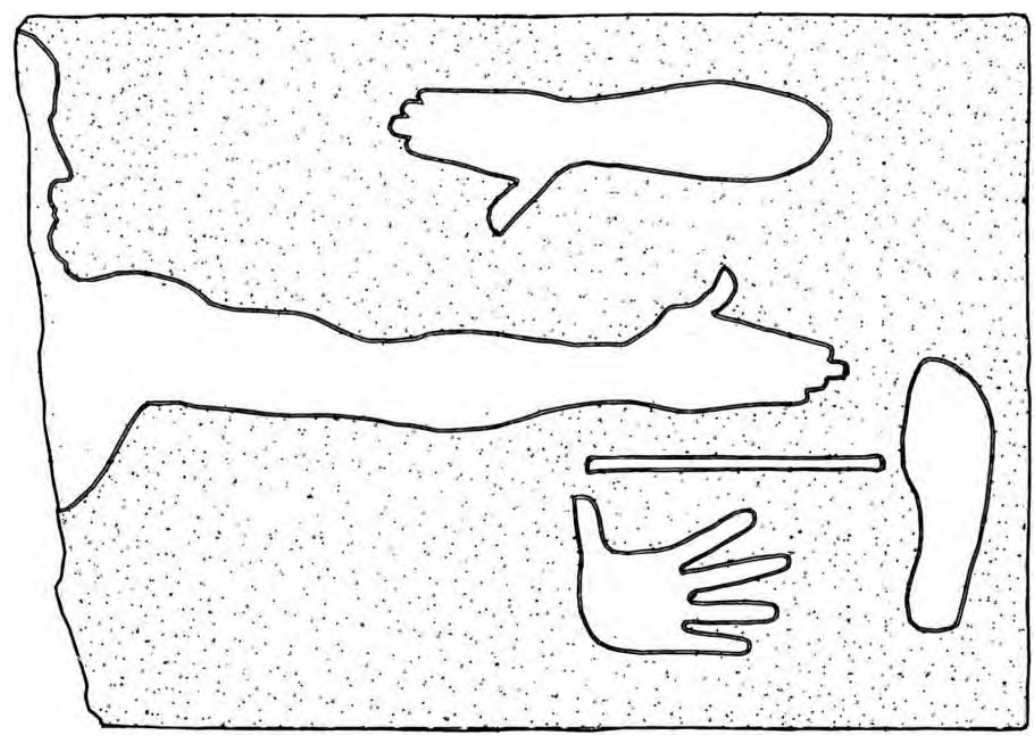

Ryc. 2. Schematyczna rycina reliefu z Salaminy (oprac. L. Żuk, na podstawie Jones 2000, ryc. 7)

Fig. 2. Schematic figure of the Salamis relief (by L. Żuk, after Jones 2000, fig. 7)

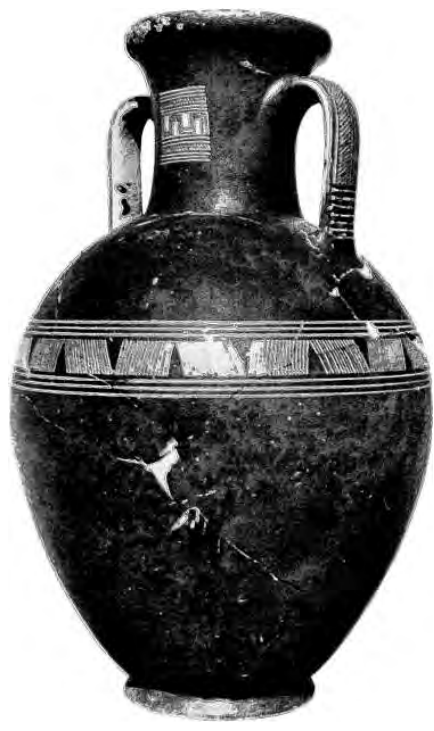

Ryc. 3a. Amfora szyjowa z okresu EG I - Agora P 20177 (rys. L. Żuk, na podstawie Coldstream 2008, tab. 1.1)

Fig. 3a. Neck amphora from period EG I - Agora P 20177 (by L. Żuk, after Coldstream 2008, tab. 1.1)

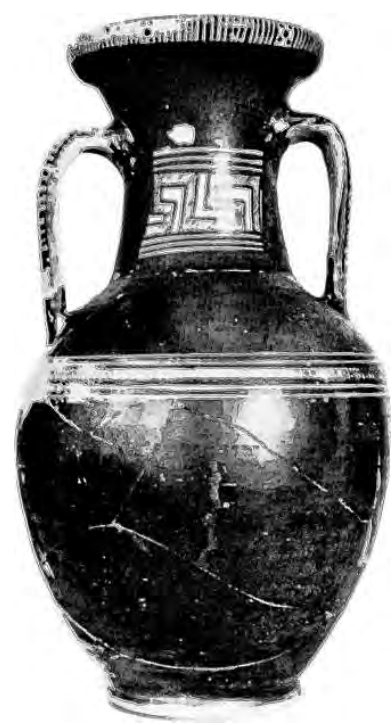

Ryc. 3b. Amfora szyjowa z okresu EG II - Keramejkos 253 (rys. L. Żuk, na podstawie Coldstream 2008, tab. 2.f)

Fig. 3b. Neck amphora from period EG II - Kerameikos 253 (by L. Żuk, after Coldstream 2008, tab. 2.f) 


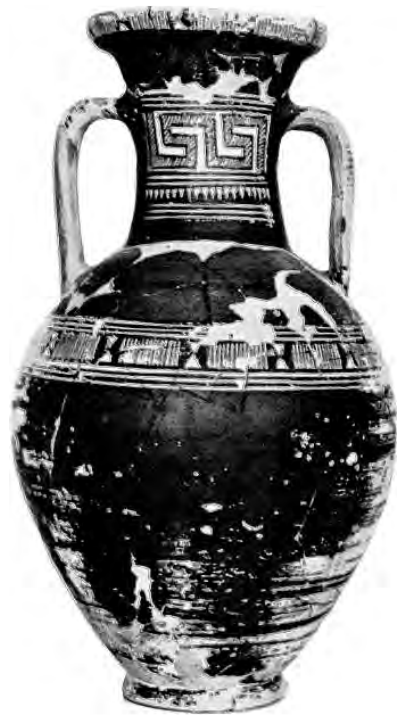

Ryc. 4a. Amfora szyjowa z okresu MG I - Keramejkos 2155 (rys. L. Żuk, na podstawie Coldstream 2008, tab. 3.a)

Fig. 4a. Neck amphora from period MG I - Kerameikos 2155 (by L. Żuk, after Coldstream 2008, tab. 3.a)

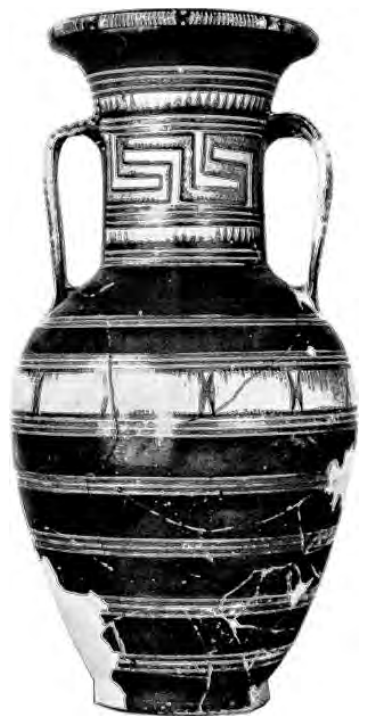

Ryc. 4b. Amfora szyjowa z okresu MG II - Keramejkos 255 (rys. L. Żuk, na podstawie Coldstream 2008, tab. 4.a)

Fig. 4b. Neck amphora from period MG II Kerameikos 255 (by L. Żuk, after Coldstream 2008, tab. 4.a)

Mamy wreszcie, oprócz wspomnianego kapitelu jońskiego z Paros, inne starożytne ewidencje materialne odnoszące się bezpośrednio do miar i zasad proporcji. Są to dwa reliefy metrologiczne. Jeden z nich pochodzi z Salaminy (ryc. 2), a datuje się go w przybliżeniu na IV w. przed Chr. (obecnie w Muzeum w Pireusie, inw. 5352). Wyryto na nim standardy dla miar linearnych, m.in. takie jak: stopa, rozciągnięte ramiona czy łokieć (Dekoulakou-Sideris 1990, s. 445-451, ryc. 2, 3; Jones 2000, ryc. 5). Drugi relief, znaleziony na początku XVII w. ery nowożytnej, datowany na ok. V w. przed Chr., o znaczeniu bardziej symbolicznym niż praktycznym, gdyż pełnił prawdopodobnie funkcję szyldu wskazującego budynek mierniczych, znajduje się w zbiorach Ashmolean Museum w Oxfordzie - inw. AN. Michaelis 83 (Dekoulakou-Sideris 1990, ryc. 4; Jones 2000, ryc. 4; Michaelis 1883, s. 336, tab. XXXV). Przedstawia on tors nagiego mężczyzny, oddany schematycznie w technice reliefu wypukłego, ukazany z rozpostartymi w linii prostej ramionami, oraz stopę wypełniają one tympanon. Można stwierdzić, że obie powyżej wymienione płyty pokryte reliefem dostarczają nam wizualnych danych wskazujących przede wszystkim na to, iż starożytne wzorce miar były antropometryczne i odnoszono je najczęściej do naturalnych proporcji ludzkiego ciała oraz jego elementów. W książce Miary i ludzie (1970), poświęconej historycznym aspektom rozwoju metrologii, Witold 
Kula pokazuje powszechność takich miar i pisze, że człowiek mierzył świat sobą, a miary te były łatwe do zrozumienia i praktyczne. Kwestią namysłu badawczego powinno pozostawać przejście od wyobrażeń konkretnych - czyli od „swojego palca/stopy” - do abstrakcyjnych, czyli ,palca lub stopy w ogóle”, sam proces wyabstrahowania się pojęcia stopy czy łokcia jako jednostki miary (Kula 1970, s. 43-46).

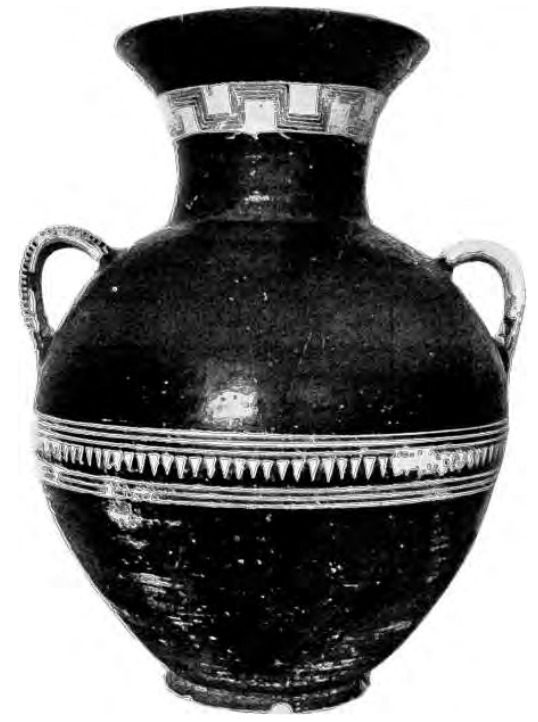

Ryc. 5a. Amfora brzuszna z okresu EG I - Agora P 19228 (rys. L. Żuk, na podstawie Coldstream, 2008, tab. 1.a)

Fig. 5a. Belly amphora from period EG I - Agora P 19228 (by L. Żuk, after Coldstream 2008 tab. 1.a)

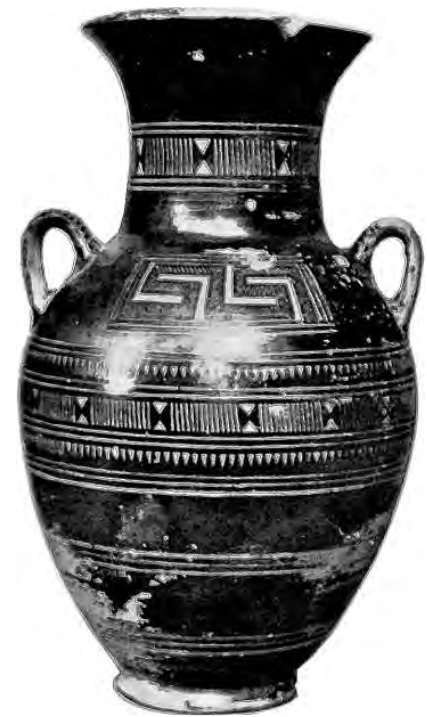

Ryc. 5b. Amfora brzuszna z okresu MG I - Eleusis 700 (rys. L. Żuk, na podstawie Coldstream 2008, tab. 3.1)

Fig. 5b. Belly amphora from period MG I - Eleusis 700 (by L. Żuk, after Coldstream 2008, tab. 3.1)

Wspomniane przed chwilą greckie reliefy metrologiczne są wykorzystywane do takich ustaleń, ale przede wszystkim do konfrontacji danych pochodzących z rozmaitych źródeł - literackich, ikonograficznych i materialnych, na żmudnej drodze prób rekonstruowania konkretnych antycznych jednostek miar oraz ich zastosowania w znanych nam dziełach. Te pokrótce przytoczone wybrane przykłady antycznych danych metrologicznych pochodzących ze świata greckiego nieodparcie pokazują, iż badanie tych zagadnień na gruncie archeologii klasycznej, w szczególności w studiach nad rzeźbą oraz architekturą, może być i jest przedmiotem refleksji.

Przechodząc do zasadniczego tematu niniejszego artykułu, czyli do attyckiej ceramiki geometrycznej, chciałabym wskazać wybrane możliwości interpretacji jej zdobnictwa także pod kątem zastosowania zasad metrologicznych. Omawiane źródła 


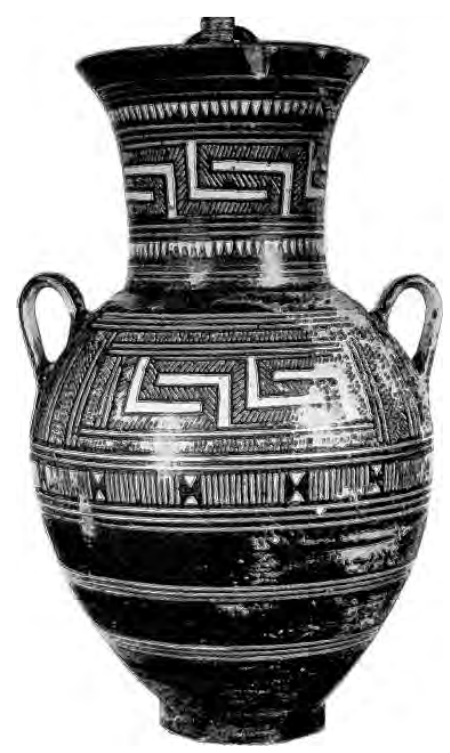

Ryc. 6. Amfora brzuszna z okresu MG II - Keramejkos 825 (rys. L. Żuk, na podstawie Coldstream 2008, tab. 5.g)

Fig. 6. Belly amphora from period MG II - Kerameikos 825 (by L. Żuk after Coldstream 2008, tab. 5.g)

odnoszą się do starożytnych czasów przed-matematycznych, gdyż attycką ceramikę geometryczną datować można na okres ok. 900-700 przed Chr. (Coldstream 2008, s. 330), a jeśli włączymy w te rozważania także źródła protogeometryczne, to ów czas wydłuża się jeszcze o ponad 100 lat (Lemos 2002, s. 24-26). Sądzę, iż tę ceramikę można potraktować przede wszystkim jako wyraz kolektywnej świadomości „wytwórczej” czy „,artystycznej”, w której myślenie „porządkujące” musiało być bardzo istotne. Wskazują na to liczne świadectwa wyjątkowego zestandaryzowania oraz powtarzalności wzorów wypracowanych jako obowiązujący język jej dekoracji, który można obserwować w perspektywie ponad dwóch stuleci. Udaną próbę odnalezienia modułu, według którego ozdobiono pojedynczy, wyróżniający się okaz naczynia geometrycznego, a konkretnie późnogeometrycznej, monumentalnej amfory, będącej pierwotnie pomnikiem nagrobnym ustawionym na pochówku z cmentarzyska Dipylon w Atenach (inw. Ateny NM 804), zaprezentował Bernard Andreae (1979). W dalszej części niniejszego tekstu odniosę się do owej drobiazgowej analizy.

Jednak wcześniej warto wskazać na studia nad większymi seriami naczyń attyckich, które prowadził pod kątem rozpoznania jakichś reguł arytmetycznych stosowanych do ich zdobienia m.in. J. Leonard Benson $(1982,1987,1988)$. Pokazały one w przekonujący sposób, że od początku wytwórczości ceramiki geometrycznej zmierzano do takiego zaplanowania systemu jej zdobień, aby osiągnąć efekt ogólnego zharmonizowania pojemnika i jego dekoracji. Chodzi przede wszystkim o pro- 


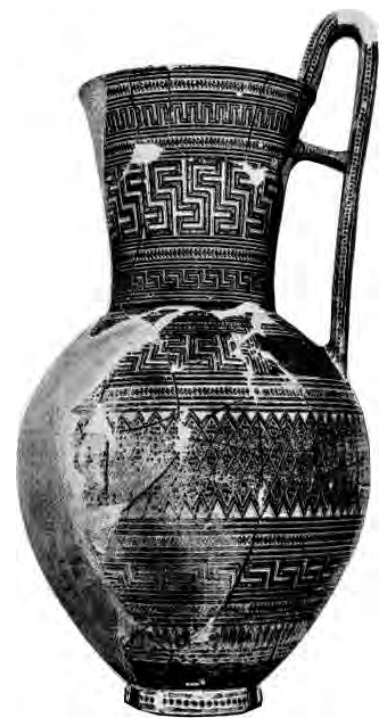

Ryc. 7. Dzban z okresu LG I - Ateny NM 812 (rys. L. Żuk, na podstawie Coldstream 2008, tab. 7.e)

Fig. 7. Pitcher from period LG I - Athens NM 812 (by L. Żuk, after Coldstream 2008, tab. 7.e)

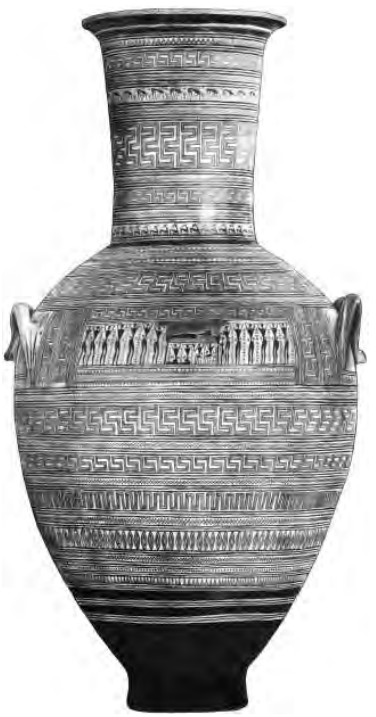

Ryc. 8. Amfora Mistrza z Dipylonu, okres LG I Ateny NM 804 (rys. M. Święszkowska, na podstawie zdjęcia E. Bugaj)

Fig. 8. Dipylon Master amphora, period LG I Athens NM 804 (by M. Święszkowska, after the photo by E. Bugaj)

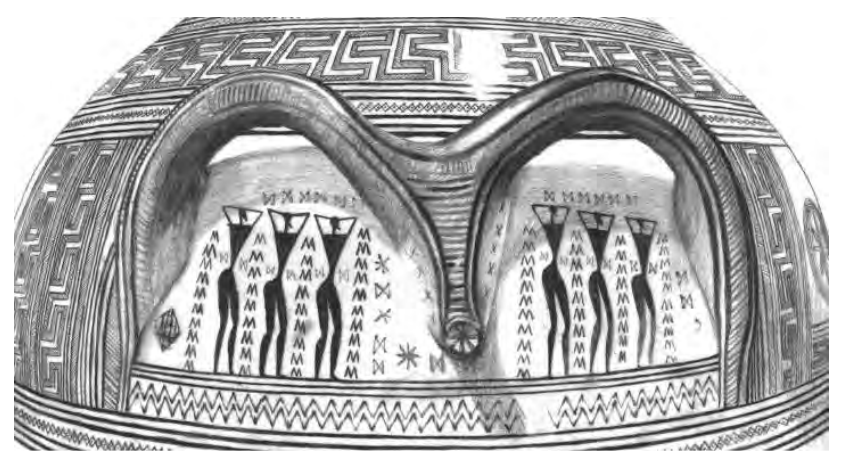

Ryc. 8a. Amfora Mistrza z Dipylonu, okres LG I, detal z uchwytem i dekoracją figuralną przedstawiającą żałobniczki - Ateny NM 804 (rys. M. Święszkowska, na podstawie zdjęcia E. Bugaj)

Fig. 8a. Dipylon Master amphora, period LG I, detail with a handle and figurative decoration of mourning women - Athens NM 804 (by M. Święszkowska, after the photo by E. Bugaj)

porcjonalne zestawienie pasów dekoracyjnych wąskich z tymi szerokimi, ornamentyki biegnącej horyzontalnie $\mathrm{z}$ tą usytuowaną pionowo, jak również o powiązanie elementów dekoracyjnych brzuśca i szyjki. W miarę rozwoju techniki zdobnictwa geometrycznego ceramiki attyckiej oraz następującego skomplikowania jej form 
powstał na powierzchni naczyń jednolity układ ornamentacyjny, łączący elementy pionowe z poziomymi w zwartą całość (por. ryc. 7 i 8). Wydaje się, że rzemieślnicy zwracali szczególną uwagę na zharmonizowanie zarówno ilościowych, jak i jakościowych aspektów dekoracji. Zharmonizowanie ornamentyki w okresie geometrycznym konstytuuje to, co późniejsi Grecy nazywali czy też rozumieli jako symmetria, a my w nowożytności włączyliśmy do kategorii estetycznych (Benson 1987, s. 1). Wszystkie te zabiegi wypada jednak uznać za mniej lub bardziej intuicyjne, wynikające, jak już wspomniano, $\mathrm{z}$ jednej strony $-\mathrm{z}$ doświadczenia wytwórczego (postawy poręcznościowej) i doświadczania swego ciała, a $z$ drugiej - być może z upodobań i dystansowania się już od tej praktycznej postawy. W każdym razie nabywana najprawdopodobniej przez producentów w trakcie wytwarzania tej ceramiki świadomość wagi i oddziaływania konkretnych rozwiązań wizualnych dekoracji jej powierzchni jest dla nas dzisiaj dobrze rozpoznawalna.

Aby pokrótce przedstawić w układzie chronologicznym wybrane źródła, które mogą potwierdzić to, co powiedziano, można porównać, podobnie jak uczynił to wspomniany J.L. Benson w tekście „Ratio in Attic Geometric Vase Decoration” [Proporcje w dekoracji geometrycznej ceramiki attyckiej] (1987), na przykład attyckie wczesno-, środkowo- i późnogeometryczne amfory szyjowe oraz amfory barkowe. Takie zestawienie pozwala zaobserwować wiodące tendencje rozwoju dekoracji tej ceramiki. Można zauważyć na przykładach wczesnogeometrycznych amfor szyjowych (EG I: ok. 900-875 przed Chr.) ${ }^{4}$, iż na egzemplarzu urny pochodzącej z pochówka wojownika na terenie ateńskiej Agory (inw. Agora P 20177; Blegen 1952, s. 290-291, tab. 74:a, b; Coldstream 2008, tab. 1.1; Whitley 1991, tab. 23) wykonano izolowany i wertykalnie ustawiony prostokąt na szyjce, wypełniony zakreskowanym meandrem (jego formą jeszcze uproszczoną, jaką jest wzór blankowy). Taśma pośrodku panelu ze wzorem blankowym flankowana jest $\mathrm{z}$ góry i z dołu pasami zdwojonych, potrójnych linii prostych, między którymi biegnie zygzak. To prostokątne „okno" dekoracji na szyjce jest skontrastowane z biegnącą dookoła brzuśca ciągłą wstęgą ornamentacyjną, ulokowaną tuż powyżej jego największej wydętości. Wstęgę tworzy szeroki zygzak wykonany ze zwielokrotnionych, równolegle do siebie usytuowanych kresek, który jest ograniczony od góry i dołu potrójnymi, ciągłymi liniami dookolnymi (ryc. 3a).

\footnotetext{
${ }^{4} \mathrm{~W}$ tekście posługuję się skrótami: EG, MG, LG powszechnie stosowanymi w literaturze przedmiotu odnośnie do greckiej ceramiki geometrycznej, ukutymi z pierwszych liter anglojęzycznych nazw następujących po sobie faz chronologicznych, oznaczających odpowiednio: wczesno-, środkowo- i późnogeometryczną. Podział chronologiczny attyckiej ceramiki geometrycznej przyjmuję w wersji zaproponowanej przez Johna Nicolasa Coldstreama w 1968 r. (wyd. 2 uzupełnione monografii Greek Geometric Pottery, z którego tutaj korzystam, ukazało się w 2008 r.). Szerzej na temat metod ustalania chronologii w świecie greckim, a głównie w Attyce okresu tzw. wieków ciemnych oraz funkcjonujących w nauce schematów periodyzacyjnych dla tego regionu, w: Whitely 1991, s. 80-86.
} 
Biorąc pod uwagę kolejny egzemplarz, typowy już dla następnej fazy okresu wczesnogeometrycznego (EG II: ok. 875-850 przed Chr.), pochodzący tym razem z pochówka na cmentarzysku Keramejkos w Atenach (inw. Ker 253; Coldstream, 2008, tab. 2.f; Kübler, 1954, tab. 25), można zauważyć, iż dekoracyjne okno na szyjce staje się większe, bardziej zbliżone do kwadratu, i w porównaniu z wąskim, dookolnym pasem fryzu, który obiega brzusiec w górnej części, tuż pod dochodzącymi do niego uchami, dominuje na naczyniu (ryc. 3b). Panel na szyi wypełniony jest, podobnie jak na naczyniu opisanym powyżej, zakreskowaną wewnątrz taśmą meandra, jednak już nie blankowego, ale o zwielokrotnionych złamaniach, który jest flankowany z góry i z dołu pasami potrójnych linii prostych. Natomiast fryz poziomy, obiegający brzusiec, tworzą potrójne linie proste ograniczające z góry i od dołu motyw rozciągniętego zygzaka, ulokowany między nimi.

Na wybranych przykładach typowej dekoracji kolejnych amfor geometrycznych, pochodzących z cmentarzyska Keramejkos, a chronologicznie określonych na fazę środkowogeometryczną, można zaobserwować, że partie brzuśca i szyjki dekorowane są w dalszym ciągu rozłącznie, a nawet jest to określane jako dekoracja antagonistyczna (Benson 1987, s. 6; Marwitz 1959, s. 62-64), tzn. na szyjce umieszcza się motyw wertykalny, ogniskujący, a na brzuścu biegnący wokół, horyzontalny (ryc. 4a). Powoduje to także efekt wyraźnego oddzielania się tych partii naczynia. Dekoracja samego brzuśca również z reguły nie tworzy jeszcze zwartej całości, ale rozpada się na wiele pasm (Boardman 1998, s. 23-24). Niemniej malujący naczynia zaczną już na tym etapie wykazywać tendencję do zapełniania rytmicznie wybranym motywem ornamentacyjnym całej powierzchni pojemnika, dzięki czemu osiągnięta zostanie bardziej harmonijna całość (ryc. 4b). Na amforze szyjowej Keramejkos 2155 datowanej na okres MG I (850-800 przed Chr.), pochodzącej z pochówka nr 36 (Coldstream 2008, tab. 3.a; Kübler 1954, tab. 29), jest widoczny sporych rozmiarów panel (metopa/okno) na szyjce (ryc. 4a). Zapełnia on większość jej powierzchni, a utworzony został z szerokiej taśmy szrafowanego wewnątrz meandra, ograniczonego z dołu i z góry pasmami potrójnych linii ciągłych, przy czym na dole dodatkowo ulokowana została jeszcze taśma ornamentu ,wilczych zębów”. Dekoracyjny dookolny pas na brzuścu tego naczynia również został bardziej rozbudowany niż na uprzednio omówionych przykładach. Pomiędzy pasmami biegnących dookolnie potrójnych linii ciągłych wykonano szeroką taśmę, na którą składają się wydłużone formy prostokątne, o wnętrzach wypełnionych pionowymi kreseczkami, równoległymi względem siebie. Owe wydłużone (leżące) prostokąty są w równych odcinkach przedzielone (alternowane) małymi, kwadratowymi „,poletkami”, wypełnionymi dwoma trójkątami, które stykają się wierzchołkami.

Kolejna środkowogeometryczna amfora szyjowa pochodząca z Keramejkosu (inw. Ker 255; Coldstream 2008, tab. 4.a; Kübler 1954, tab. 31), datowana na odcinek MG II tej fazy (ok. 800-760 przed Chr.), ornamentowana jest w bardzo podobny sposób - widoczne jest powielanie i kontynuowanie określonych sposobów dekora- 
cji, wypracowanych dla konkretnych form naczyń. Formy te jednak zmieniano, i w przypadku naczynia Ker 255 (ryc. 4b) można odnotować tendencję do wysmuklania pojemników, których brzuśce stają się bardziej obłe. Dążenie do wykonywania smuklejszych form ceramicznych, jeśli chodzi o typy naczyń zamkniętych, zacznie iść $\mathrm{w}$ parze $\mathrm{z}$ tendencją do ich monumentalizowania, co nastąpi rzeczywiście w fazie późnogeometrycznej (Boardman 1998, s. 25). Na omawianej amforze szyjowej Ker 255 widać, iż oprócz panelu na szyi naczynia, który wypełnia już całą jej wysokość, oraz dookolnej, szerokiej taśmy ornamentu usytuowanego tuż powyżej największej wydętości brzuśca, wykonano również na powierzchni brzuśca, w części barkowej oraz w części dolnej, poniżej szerokiej taśmy horyzontalnej, dookolne ciągi linii potrójnych, rozmieszczonych rytmicznie, w równych odstępach od siebie. Dzięki zastosowaniu tych równych odstępów pomiędzy pasami dekoracji brzuśca i systematycznemu powtórzeniu wąskich fryzów na całej jego powierzchni, poniżej i powyżej szerokiego, uzyskano zharmonizowanie dekoracji i powiązanie jej z ornamentyką szyjki. Coraz bardziej widoczna staje się zatem tendencja do pokrywania ornamentem całej powierzchni naczynia, co wkrótce stanie się dominującym sposobem dekoracji.

Analiza sposobów zdobienia amfor innego typu - form barkowych, przeprowadzona na większej serii attyckich naczyń, również pozwoliła zaobserwować na typowych przykładach pojemników z faz wczesno- i środkowogeometrycznej tendencję do pokrywania ornamentem całej ich powierzchni w sposób zrównoważony (ryc. 5a i 5b), aż do osiągnięcia efektu widocznego na amforze o numerze inwentarzowym 825 (ryc. 6), datowanej na fazę MG II, a pochodzącej z cmentarzyska Keramejkos. Na tym egzemplarzu (Coldstream 2008, tab. 5.g; Kübler 1954, tab. 45), dzięki rozważnemu rozmieszczeniu podobnych pasów wypełnionych wzorami, zarówno na brzuścu, jak i w partii szyjki, wytwórca osiągnął jedność dekoracji obu tych części oraz ich równowagę. Zostało to jednak uczynione kosztem niedowartościowania ornamentami dolnej partii naczynia, na której widnieją jedynie dwa wąskie pasma potrójnych linii biegnących dookoła. Natomiast powyżej, w partii szyjki i w części barkowej, na wysokości uchwytów, dominują panele wypełnione zakreskowanymi taśmami dużego meandra. Otaczają je liczne pasma obramowań geometrycznych, utworzonych za pomocą wielokrotnych linii ciągłych, sznurów wilczych zębów czy innych form zygzaków. Ponadto mniej więcej pośrodku wysokości brzuśca, nieco poniżej największej jego wydętości, widoczny jest szeroki, obiegający horyzontalnie pas ornamentacyjny, na który składają się motywy analogiczne do tych widniejących na pasie opisanego powyżej naczynia Ker 2155 (por. ryc. 6 i ryc. 4a).

Wcześniejsze odmiany attyckich amfor brzusznych, o których chcę jeszcze wspomnieć, aby zilustrować dążenie dekorujących ceramikę od wykonywania umiarkowanych i rozłącznych elementów ornamentacyjnych do łączenia ich w harmonijną całość, to naczynie wczesnogeometryczne (EG I) pochodzące z pochówka na terenie Agory (inw. Agora P 19228; Coldstream 2008, tab. 1.a; Young 
1949, tab. 67.1, 68.1; Whitley 1991, tab. 25) oraz środkowogeometryczne (MG I) pochodzące $\mathrm{z}$ cmentarzyska w Eleusis (inw. Eleusis 700; Coldstream 2008, tab. 3.1). Na przykładzie wczesnej amfory - Agora P 19228 - widzimy to, co było typowe dla tego etapu, czyli zminimalizowanie dekoracji do dookolnie biegnących $\mathrm{w}$ partii szyjki i brzuśca pojedynczych taśm ornamentacyjnych, wyróżniających się na zamalowanej na czarno pozostałej powierzchni tego pojemnika (ryc. 5a). Pasmo ornamentu na wysokości szyjki, ulokowane nieco powyżej środka jej wysokości, wypełnia sznur prostego meandra blankowego, natomiast pasmo na brzuścu, umieszczone z kolei nieco poniżej jego największej wydętości, utworzone jest z dwóch taśm potrójnych linii ciągłych, pomiędzy którymi wykonano szlak „wysokiego zygzaka”, czyli stojących, stykających się wierzchołkami podstawy, zaczernionych trójkątów na jasnym tle, dzięki czemu uzyskano efekt, który bywa w literaturze określany jako „wilcze zęby”.

$\mathrm{Na}$ amforze brzusznej z cmentarzyska w Eleusis (inw. 700), datowanej na MG I (ryc. 5b), widoczne jest nagromadzenie ornamentyki geometrycznej, złożonej z tego samego, kontynuowanego i powielanego w rozmaitych konfiguracjach repertuaru motywów, który od fazy wczesnogeometrycznej był rozpowszechniany. Widać na tym naczyniu zestaw takich motywów, jak: dookolne, potrójne linie ciągłe, szlaki ustawionych wierzchołkami do góry trójkątów, panele wypełnione trójkątami stykającymi się wierzchołkami, układy pionowych, równoległych kresek, metopy wypełnione meandrem itp. Nie tworzą jeszcze zwartej całości - takiej, jaka została osiągnięta na wspomnianej już amforze brzusznej z Keramejkosu, datowanej na MG II (Ker 825; por. ryc. 6), aczkolwiek i jej dekoracja nie schodzi do samej podstawy tego pojemnika. To nastąpi dopiero w okresie późnogeometrycznym.

W finalnej fazie rozwoju stylu geometrycznego - to jest w okresie późnogeometrycznym, który został podzielony na terenie Attyki na dwa odcinki (LG I ok. 760-735 i LG II ok. 735-700), a w ich ramach wydzielono jeszcze mniejsze jednostki (Coldstream 2008, s. 330; Whitley 1991, s. 85-86) - kontynuowano wypracowane wcześniej sposoby malowania ceramiki, ale dekoracja naczyń staje się bardziej intensywna oraz złożona. Skorygowano nieco kształty naczyń, jak również systematycznie pokrywano dekoracją dolne ich partie, często aż do stópki. Doprowadziło to do tego, że ornamentowana była cała ich powierzchnia (ryc. 7 i 8). Jak już wspomniałam, naczynia stają się większe oraz pojawiają się formy monumentalne (ryc. 8), a w obręb dekoracji geometrycznej zostają coraz liczniej wprowadzone motywy figuralne (ryc. 8a). Rezultatem tych zmian jest pojawienie się stylu, który ma wiele elementów nowych, bez porzucenia wcześniejszych, geometrycznych pryncypiów. Ten styl odznacza się ponadto rozważnym zastosowaniem określonego systemu proporcji pasów dekoracji względem siebie oraz w stosunku do części naczynia.

Przed omówieniem systemu proporcji dekoracji naczyń późnogeometrycznych warto kilka słów poświęcić charakterystyce ogólnej wyrobów ceramicznych tej fazy. W okresie późnogeometrycznym nastąpił wyjątkowo mocny rozkwit produkcji ce- 
ramicznej oraz jej zdobnictwa. Jest to czas niewątpliwego wzrostu zamożności społeczeństwa Attyki oraz jego świadomości znaczenia posiadania i wykorzystywania dóbr prestiżowych, w tym również obcych wyrobów rzemiosła (Whitley 1991, s. 183, tab. 11), co ujawniało się już wcześniej. Wiele uwagi społeczność ta poświęcała, podobnie jak w fazach poprzednich, przygotowaniu zmarłemu formalnego pochówku, najczęściej bogato wyposażonego, którego pierwszorzędnym i najliczniejszym elementem była ceramika. W związku z tym groby są nadal najważniejszym dostępnym badaniom archeologicznym źródłem poznania epoki.

$\mathrm{W}$ produkcji ceramicznej i jej zdobnictwie zmiany są dyktowane przede wszystkim wewnętrznym rozwojem tej wytwórczości, wynikającym zapewne ze zmieniającego się nastawienia odbiorców, głównie elit, mających potrzebę negocjowania i demonstrowania swego statusu, często zresztą poprzez inne dobra niż ceramika, a jeśli chodzi o tę ostatnią, to właśnie na gruncie wytwórczości ceramiki grobowej. Kompozycja dekoracji naczyń jest wciąż zaaranżowana geometrycznie w postaci symetrycznie rozmieszczonych obszarów pionowych i poziomych, w których lokowane są coraz liczniej przedstawienia figuralne, tworzące sceny (ryc. 8), przy czym dominuje tematyka funeralna. Do repertuaru poprzednich wzorów dodawane są nowe, takie jak szachownica, rozmaite wzory dywanowe, listki (niektóre formujące rozety) oraz cała gama rozwiniętych meandrów (ryc. 7). Niektóre dookolne fryzy utworzone są z powtarzalnych figurek zwierząt, najczęściej pochylonych, pasących się czworonogów lub ptaków. Mnogość dekorowanych wyrobów ceramicznych z tej fazy stylu geometrycznego pozwoliła badaczom, zgodnie z metodą stosowaną w badaniu ceramiki czasów późniejszych, a zaadaptowaną na grunt archeologii klasycznej z historii sztuki, wyróżnić poszczególnych malarzy lub produkcję określonych warsztatów oraz zakres ich wpływów (Boardman 1998, s. 25). Podejście to nadal ma grono licznych zwolenników i kontynuatorów, ale bywa także coraz częściej krytykowane 5 .

Dla Aten w fazie LG I wyróżniono tzw. Warsztat Dipyloński oraz naczynia, które miał dekorować malarz określony jako Mistrz Amfory z Dipylonu, pracujący w pierwszej połowie VIII stulecia przed Chr. (Coldstream 2008, s. 29-37; Nottbohm 1943, s. 1-31). Jego podejście do ornamentowania powierzchni ceramiki można najlepiej ocenić na podstawie dużych naczyń wykonanych jako pomniki grobowe, na czele ze wskazaną wzorcową dla tego wykonawcy amforą brzuszną Ateny NM 804, pochodzącą z grobu nr 2 lub $4 \mathrm{z}$ cmentarzyska przy Bramie Dipylońskiej w Atenach (ryc. 8; Coldstream 2008, tab. 6; Nottbohm 1943, ryc. 7; Whitley 1991, tab. 28-29). Z tym wykonawcą lub jego warsztatem badacze powiązali ponad 40 naczyń, w tym także duży dzban z uchem wychodzącym ponad krawędź wylewu

\footnotetext{
${ }^{5}$ Krytykiem takiego postępowania jest m.in. James Whitley (na którego pracę powołuję się w tekście), promujący odmienne od estetycznego nastawienie badawcze do ceramiki greckiej okresu wieków ciemnych (por. Whitley 1991, s. 13-23, 75-80).
} 
(forma wprowadzona w tym okresie), drobiazgowo zdobiony na całej powierzchni motywami geometrycznymi bez przedstawień figuralnych, pochodzący zapewne z grobu $\mathrm{nr} 14$ również z cmentarzyska przy Bramie Dipylońskiej (inw. Ateny NM 812; Coldstream 2008, tab. 7.e), który poniżej będzie jeszcze przedmiotem analizy (ryc. 7).

W odniesieniu do problematyki miar/modułów, którymi musiano się posługiwać zapewne na etapie wyrobu samych naczyń geometrycznych, toczonych na szybkoobrotowym kole, $\mathrm{w}$ tym szczególnie form monumentalnych (1,50-1,80 m wysokości), a następnie w fazie ich malowania, warto wskazać na udane próby poszukiwania takich zasad porządkujących. Są one, jak już wspomniano, autorstwa J.L. Bensona (1982, 1987) oraz B. Andreae (1979), aczkolwiek zasad proporcji regulujących wytwarzanie attyckiej ceramiki geometrycznej, jak i relacji uwzględniających ornamentykę i kształty naczyń, a także powiązanie samej dekoracji ze sobą ze względu na jej rodzaj i motywy, poszukiwało wielu innych autorów w rozmaity sposób (por. np. Kahane 1940, s. 464-482; Marwitz 1959, s. 52-113).

J.L. Benson zaproponował jedno z prostszych ujęć dotyczących poszukiwania modułu dla wykonywania tej ceramiki i posłużył się przyjętą na wstępie nieskomplikowaną zasadą. Polegała ona na nadaniu niskiemu pasowi dekoracji wartości 1 , a wysokiemu - 2, a wynik analizy był sumarycznym stosunkiem motywów wysokich do niskich, obliczanym oddzielnie dla partii szyjki i brzuśca (wywody autora przytaczam tutaj w pewnym uproszczeniu; ich bliższe omówienie: por. Benson 1987, s. 3). W ten sposób wspomniany badacz uzyskał na przykład dla dzbana z Aten NM 812 (ryc. 7) na szyjce stosunek 2:2, a na brzuścu 4:2, co oznacza, że stosunki ornamentów pokazują w tym wypadku perfekcyjne ich zrównoważenie na szyjce, a wzmocnienie na brzuścu. Nacisk na dekorację największej wydętości brzuśca i jej podkreślenie, a zmniejszanie się tej dekoracji ku dołowi naczynia, jest możliwy do zaobserwowania. Ale ogólnie ornamentyka dzbana bez zakłóceń pokrywa całą jego powierzchnię, dając wizualne wrażenie „opływania” pojemnika czy też swobodnego zawieszenia na nim, z tendencją do zmierzania ku górze (Benson 1987, s. 3).

Odnośnie do monumentalnej amfory Ateny NM 804, na której występuje nieco większa komplikacja dekoracji - pojawiają się bowiem w jej obrębie sceny figuralne przykuwające wzrok oglądającego, poddane jednak dokładnie takim samym geometrycznym regułom wykonania jak wzory abstrakcyjne (ryc. 8 i 8a) - badacz rozbudował analizę. W jej wyniku uzyskał w partii szyjki stosunek ornamentów wysokich do niskich jako 2:4, a na brzuścu 6:6. Rezultat analizy odzwierciedla zatem wydłużenie szyjki oraz perfekcyjne zrównoważenie dekoracji brzuśca. Powierzchnia dekorowana jest bez przerw, ale wzrok przyciąga przede wszystkim scena figuralna na wysokości uchwytów, która jest skontrastowana $\mathrm{z}$ wysokim fryzem szyjki zawierającym meander schodkowy. Dominacja sceny figuralnej z brzuśca jest jednak nieco stłumiona przez zwracajace także uwagę fryzy zwierzęce z szyjki (Benson 1987, s. 3). 
Uważam, że nie wszystkie analizy dekoracji naczyń geometrycznych przeprowadzone przez J.L. Bensona są w równiej mierze przekonujące. Na przykład rozważania nad zasadą ornamentacji dzbana Ateny NM 812 wydają się wpisywać greckich wytwórców w zaplanowane $\mathrm{z}$ góry myślenie według proporcji. Jednak w przypadku monumentalnej amfory dipylońskiej Ateny NM 804 trudno już zaprzeczyć podejściu wykonawcy do dekoracji naczynia poprzez nastawienie się na zastosowanie dopracowanego systemu proporcji, na zorientowanie się na zasadę, która uporządkuje i zrównoważy złożoną strukturę ornamentyki.

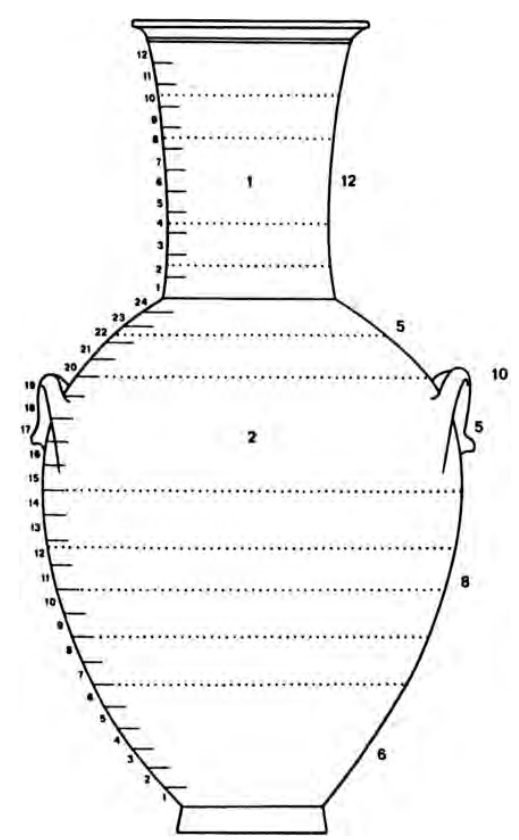

Ryc. 9. Schematyczny szkic Amfory Mistrza z Dipylonu - Ateny NM 804, ukazujący system jej dekoracji zgodnie z systemem proporcji wskazanym przez B. Andreae (oprac. E. Bugaj, na podstawie Andreae 1979, tab. I.2)

Fig. 9. Schematic draft of a Dipylon Master amphora - Athens NM 804, showing system of its decoration along with the system of proportions suggested by B. Andreae (by E. Bugaj, after Andreae 1979, tab. I.2)

Ostatnią z omawianych prób poszukiwania modułu mogącego mieć zastosowanie w trakcie wytwarzania amfory Ateny NM 804 jest zapowiadana inna analiza, którą przeprowadził Bernard Andreae. Przywołam ją w wielkim skrócie. Wspomnieć należy, iż Amfora Mistrza Dipylonu jest dokładnie dwa razy wyższa niż największa wydętość jej brzuśca, a wysokość szyi jest połową wysokości brzuśca. Całkowita wysokość naczynia wynosi $1,55 \mathrm{~m}$, przy czym partia podstawy jest częściowo 
uszkodzona. Wychodząc z założenia, że dekoracja tak monumentalnego naczynia z przeznaczeniem na pomnik nagrobny, który miał być widoczny, nie była możliwa bez wcześniejszego zaplanowania opierającego się na jakichś regułach, badacz żmudnie poszukiwał konkretnej zastosowanej miary. Skrupulatnie zestawiając i konfrontując wszystkie strefy ornamentu od dołu ku górze, B. Andreae wydzielił 36 dających się rozpoznać odcinków - stref horyzontalnych dekoracji o tej samej lub bardzo zbliżonej wysokości. Wskazał 24 strefy na brzuścu i 12 na szyjce, natomiast rozpoznany moduł przypadający na strefę dekoracyjną wynosił $\mathrm{w}$ jednostkach naszego systemu ok. 4,66 cm (Andreae 1979, s. 8). Przyjmując, że naczynie dekorowano od dołu, w dalszym toku swej analizy uczony wskazał, że 6 wspomnianych stref dekoracyjnych wykonano w dolnej części brzuśca, 8 poniżej największej wydętości, 10 stref to pas powyżej największej wydętości i część barkowa, a 12 stref stanowi szyję (por. ryc. 9). W sumie daje to zasadę rosnącego podziału elementów dekoracyjnych, opartą na przyjętym module (Andreae 1979, s. 10-11). Innym efektem tej analizy jest ponadto wykazanie funkcjonowania ówcześnie jakiegoś systemu „triadycznego”, gdyż wszystkie wydzielane przez badacza odcinki dawały się także dzielić przez 3. Pomimo zastosowania owej miary nie należy jednak sądzić, że dekoracja amfory została wykonana $\mathrm{w}$ jakiś mechaniczny sposób, ponieważ poszczególne odcinki nie są idealnie równe - natomiast sprawiają takie wrażenie, i najprawdopodobniej o to chodziło.

Jeżeli postawimy pytanie o cel wykonania owego monumentalnego pojemnika ceramicznego, to jako pierwsza narzuci się jego funkcja, którą znamy: to była semata - pomnik grobowy, mający upamiętniać i zarazem uobecniać zmarłą, a co za tym idzie: umożliwiać komunikację. Nie wchodząc w nowy wątek, dotyczący interpretacji przedstawień figuralnych, a pozostając na poziomie rozważań odnośnie do zastosowanego modułu, można jeszcze dodać, że samo poszukiwanie i wypracowywanie modułu/modularyzm to także sposób komunikowania, a komunikowanie buduje wspólnotę. Sądzę, że wykonanie przez rzemieślnika, którego badacze współcześni nazwali Mistrzem Amfory z Dipylonu, monumentalnego naczynia NM 804 nie powinno być traktowane ani jako działanie matematyczne, ani artystyczne. Takie potraktowanie owego artefaktu to nadawanie mu cech dzieł nowożytnych, bez uwzględnienia perspektywy historycznej.

W podsumowaniu charakterystyki tych nielicznych, ale typowych dla poszczególnych faz rozwoju attyckiej ceramiki geometrycznej przykładów amfor można stwierdzić, że takie myślenie i działanie porządkujące, w wyniku którego powstał jeden z najbardziej ustandaryzowanych systemów zdobnictwa oparty na zestawie prostych figur geometrycznych, tworzących swoisty, bardzo rytmiczny i powtarzalny język plastyczny, to niekoniecznie dowód na początki klasycznego myślenia matematycznego, które rozwinie się później. Wydaje się, że za matematykami należy uznać (Høyrup 2000, s. 44-48), iż między ornamentyką wizualnie geometryczną, datowaną na wczesną epokę żelaza, a późniejszymi formalnymi zasadami matema- 
tyki nie ma żadnego prostego i bezpośredniego związku, na co warto zwrócić uwagę, wyrażając sprzeciw wobec dominujących naiwnych interpretacji. Bliższe spojrzenie na dekorację attyckiej ceramiki geometrycznej pozwala dostrzec, że bardziej chodziło o uzyskanie oczekiwanych wrażeń wizualnych, o zakomunikowanie czegoś obrazem niż zachowanie precyzyjnie kontrolowanej regularności. Szczególnie widoczne stanie się to w momencie coraz obficiej wprowadzanych motywów figuralnych w obręb dekoracji złożonej ze szczelnie pokrywających powierzchnie naczyń motywów czysto abstrakcyjnych. Doprowadzi to pod koniec fazy LG II do całkowitego rozluźnienia rygorów i precyzji rysunku zgeometryzowanego, a z czasem do zmiany stylu.

Niemniej jednak uważam próby poszukiwań reguł porządkujących dekorację analizowanej ceramiki greckiej okresu geometrycznego za w pełni zasadne. Kładąc nacisk na aspekty komunikacyjne i znaczeniowe owych wyrobów, nie należy pomijać z jednej strony tych techniczno-praktycznych, a z drugiej - kwestii upodoban, które staną się w nowożytności kategoriami estetycznymi. Próbując analizować najpierw morfologię, a następnie tektoniczną syntaksę owej dekoracji, tj. układ i wzajemne powiązanie elementów konstrukcji ornamentów w stosunku do siebie oraz samego naczynia, można pokazać, iż wizualne elementy dekoracji są zastosowane stylistycznie $\mathrm{w}$ ramach całkowicie zorganizowanego, tektonicznie koherentnego schematu. Analizy tego typu uzmysławiają, że w takich dziełach, jak attycka ceramika geometryczna można także doszukać się śladów dyspozycji jej twórców do wizualnego oddawania doświadczanej rzeczywistości, do prób ukazywania natury rzeczy - physis - i do prób uogólniania tych doświadczeń.

Warto także zauważyć parataktyczny układ wczesnych fryzów figuralnych, w tym głównie zwierzęcych, które dokładnie powielają zasady motywów abstrakcyjnych. Być może są one przejawem wczesnych konceptualizacji, prób tworzenia abstrakcyjnych pojęć. Wykonywanie bowiem multiplikowanych rzędów tego samego ptaka czy jelenia można odczytywać jako zmierzanie ku syntezie tego, czym jest ptak lub jeleń - ale w tym miejscu na domniemaniach musimy poprzestać. Niemniej jest to kolejny pretekst do dyskusji o początkach racjonalnego i abstrakcyjnego myślenia w Grecji, które niektórzy badacze chcieliby datować wcześniej, niż wynika to z zachowanych tekstów filozoficznych. Ceramika wykonywana w stylu geometrycznym jest nieodłącznie brana pod uwagę w tej dyskusji.

\section{BIBLIOGRAFIA}

Andreae B.

1979 Zum Dekorationssystem der geometrischen Amphora 804 im Nationalmuseum Athen. W: G. Kopcke, M. B. Moore (red.), Studies in Classical Art and Archaeology. A Tribute to Peter Heinrich von Blanckenhagen (s. 1-16). New York: J. J. Augustin. 
Benson J. L.

1982 Picture, Ornament, and Periodicity in Attic Geometric Vase-Painting. The Art Bulletin, 64(4), s. 535-549.

Benson J. L.

1987 Ratio in Attic Geometric Vase Decoration. Source: Notes in the History of Art, 6(2), s. 1-7.

Benson J. L.

1988 Symptom and Story in Geometric Art. BABesch, 63, s. 69-76.

Blegen C. W.

1952 Two Athenian Grave Groups of about 900 B.C. Hesperia, 21(4), s. 279-294.

Campbell G. (red.)

2007 The Grove Encyclopedia of Classical Art and Architecture (t. 1 i 2). Oxford: Oxford University Press.

Coldstream J. N.

2008 Greek Geometric Pottery. A Survey of Ten Local Styles and Their Chronology (Updated Second Edition). Bristol: Bristol Phoenix Press.

Dekoulakou-Sideris E.

1990 A Metrological Relief from Salamis. American Journal of Archaeology, 94(3), s. 445-451.

Heller M.

2013 Logos wszechświata. Zarys filozofii przyrody. Kraków: Znak.

Høyrup J.

2000 Geometrical Patterns in the Pre-Classical Greek Area. Prospecting the Borderland between Decoration, Art, and Structural Inquiry. Revue d'histoire des mathématiques, 6, s. 5-58.

Jones M. W.

2000 Doric Measure and Architectural Design 1: The Evidence of the Relief from Salamis. American Journal of Archaeology, 104(1), s. 73-93.

Jones M. W.

2001 Doric Measure and Architectural Design 2: A Modular Reading of the Classical Temple. American Journal of Archaeology, 105(4), s. 675-713.

Kahane P.

1940 Die Entwicklungsphasen der attisch-geometrischen Keramik. American Journal of Archaeology, 44(4), s. 464-482.

Kula M.

1970 Miary i ludzie. Warszawa: Książka i Wiedza.

Kübler K.

1954 Kerameikos. Ergebnisse der Ausgrabungen. Die Nekropole des 10. bis 8. Jahrhunderts (t. 1: tekst, t. 2: tablice). Berlin: Walter de Gruyter \& Co.

Lemos I. S.

2002 The Protogeometric Aegean. The Archaeology of the Late Eleventh and Tenth Centuries $B C$. Oxford: Oxford University Press.

Marwitz H.

1959 Kreis und Figur in der attisch-geometrischen Vasenmalerei. Jahrbuch des Deutschen Archäologischen Instituts, 74, s. 52-113.

Michaelis Ad.

1883 The Metrological Relief at Oxford. The Journal of Hellenic Studies, 4, s. 335-350.

Nottbohm G.

1943 Der Meister der grossen Dipylon-Amphora in Athen. Jahrbuch des Deutschen Archäologischen Instituts, 58, s. 1-31. 
Pałubicka A.

2006 Myślenie w perspektywie poręczności a pojęciowa konstrukcja świata. Bydgoszcz: Oficyna Wydawnicza Epigram.

Pollitt J. J.

1990 The Art of Ancient Greece: Sources and Documents. Cambridge: Cambridge University Press.

Russo L.

2005 Zapomniana rewolucja. Grecka myśl naukowa a nauka nowoczesna. Kraków: Universitas.

Stewart A.

1978 The Canon of Polykleitos: A Question of Evidence. The Journal of Hellenic Studies, 98, s. $122-131$.

Suppes P.

1991 Rules of Proportion in Architecture. Midwest Studies in Philosophy, 16, s. 352-358.

Tatarkiewicz W.

1988 Historia estetyki (t. 1: Estetyka starożytna). Warszawa: Arkady.

Tobin R.

1975 The Canon of Polykleitos. American Journal of Archaeology, 79(4), s. 307-321.

Whitley J.

1991 Style and Society in Dark Age Greece. The Changing Face of a Pre-Literate Society 1100-700 BC. Cambridge: Cambridge University Press.

Young R. S.

1949 An Early Geometric Grave Near the Athenian Agora. Hesperia, 18(4), s. 275-297.

\section{A FEW REMARKS ON ANCIENT METROLOGY AND ON ATTIC GEOMETRIC POTTERY AND ITS DECORATION}

\section{Su m mary}

Far from being the most common issue, recognising connections between visual arts, in particular between the principles of construction and decoration of works of art, and certain identifiable rules of metrology has a long tradition in the study of Greek art. In general, topics related to the study of the ancient canon in visual arts and architecture and the development of metrological systems are undertaken in relation to the reflection on the rise of numerical systems in ancient mathematics and the functional applications of geometry, as well as to the attempt to grasp the ancient understanding of the meanings of the commensurable and incommensurable.

Greek architecture and visual arts provide many examples of the use of mathematics and there are numerous references to this subject in the written sources. For example, Greek temples and proportions used for their construction are described by Vitruvius, whereas Pliny the Elder refers to the Canon of Polykleitos and generally discusses the principles of proportions used in the fifth and fourth centuries BC respectively. And last but not least, we have ancient material records in the form of two metrological reliefs. Inscribed on the one from Salamis are standards for linear measures, including among others, foot, hand-span and cubit (Museum of Piraeus, inv. 5352). The 
second relief is in the collections of the Ashmolean Museum in Oxford (inv. AN. Michaelis 83). These reliefs offer us a visual picture of the ancient standards of measurement and reveal that they were most frequently related to the natural proportions of the human body and its parts.

The above-mentioned remarks concern the classical times, whereas in the paper that I would like to present I intend to point out the selected possibilities of interpreting earlier sources from the perspective of application of metrological principles, namely the Attic Geometric pottery dated to about 900-700 BC. It seems to me that Geometric pottery can be treated primarily as an expression of the collective 'artistic' consciousness, in which 'ordering' thinking had to be very important as evidenced in great numbers by the exceptional standardisation and repetition of patterns developed as the working language of this decoration, which can be easily observed in the perspective of more than two centuries. As successful attempts to identify a module according to which single outstanding examples of Geometric vessels were decorated (such as a large amphora now located in the National Museum in Athens (inv. NM 804) and decorated by the so-called Dipylon Master), have already been presented in the literature (Andreae 1979), I will only briefly refer to this scrupulous analysis. Similar studies, looking for ratio and arithmetic rules according to which the expected proportions of pottery decoration were achieved in those "pre-mathematics" times, were also made for a larger series of Attic pottery analysed in chronological order, from Early Geometric till Late Geometric period (Benson 1987). Analyses have revealed that from the beginning of the production of Geometric pottery there was an attempt to plan the system of decoration so as to achieve the harmonizing effect, i.e. the proportional made of wide and narrow decorative bands, as well as relations between decorative elements of the body and neck. However, all these attempts seem to have been more or less intuitive, resulting on the one hand from the production experience and from the preferences on the other. According to Benson, the amphora of the Dipylon Master is the first to clearly confirm the rule-oriented approach of its maker, a rule that was to organise and balance the complex structure of the decoration. The vessel also shows the potential of Geometric ornamentation and its idiom, in which some arithmetical sense can be traced.

I think, however, that such a way of thinking and ordering, which resulted in the development of the one of the most standardised decorative systems based on a set of simple geometric shapes, forming a kind of rhythmic and repetitive artistic language, does not necessarily have to be the proof of the origins of the classical mathematical thinking that will develop later. I would agree with the mathematicians (Høyrup 2000) that there is no simple nor direct relationship between the visually geometric ornamentation dating to the Early Iron Age and the subsequent formal rules of mathematics, which is worth emphasising in order to oppose the dominant naive interpretation. On closer scrutiny we see that the decoration of Attic Geometric pottery was more about producing the expected visual experience, about communicating something with the image rather than about adhering to a precisely controlled regularity. This becomes particularly evident when pottery decorators started to introduce more and more figural motifs within the purely abstract motifs tightly covering the surfaces of the vessels.

Nevertheless, I believe attempts to identify rules ordering the decoration of the analysed Greek pottery of the Geometric period to be fully justified. Focusing on communication and semantic aspects of these works, we cannot ignore the aesthetic aspects that are closely related to them. Thus, we should first try to analyse the morphology of decoration and then its tectonic syntax, i.e. the structure and interconnections of structural elements of ornaments in relation to one 
another and to the vessel itself. This will make it possible to show that the visual elements forming the decoration of the vessel were stylistically applied within a fully organised, tectonically coherent scheme. As a result, this type of analysis makes it clear that in works such as the Attic Geometric pottery we can also detect traces of the craftsmen disposition towards visioning a physical reality, of attempts to portray the nature of things - physis.

Written by Ewa Bugaj 